Natalia KRAWCZYSZYN-POCHŁOPIEŃ

Uniwersytet Ekonomiczny we Wrocławiu

\title{
KIERUNKI I DYNAMIKA ROZWOJU TRANSGRANICZNYCH SIECIOWYCH PRODUKTÓW TURYSTYCZNYCH NA OBSZARZE EUROREGIONÓW GLACENSIS I PRADZIAD
}

\section{Wstęp}

Polsko-czeska transgraniczna współpraca w turystyce, dzięki sprzyjającym warunkom polityczno-ekonomicznym, m.in. jednoczesnemu wejściu w życie postanowień Układu z Schengen w Polsce i Czechach oraz pojawieniu się dodatkowych możliwości zewnętrznego wsparcia ze środków unijnych, na przestrzeni ostatnich kilkunastu lat wyraźnie się zintensyfikowała. W efekcie połączone polsko-czeskie obszary przygraniczne, euroregiony (traktowane tu w rozumieniu przestrzennym, a nie instytucjonalnym), zaczęły stawać się wspólną przestrzenią turystyczną, w której powstające nowe produkty turystyczne nie podlegają ograniczeniu przez granicę państwa. $Z$ uwagi na fakt, że polsko-czeska granica przebiega po terenach górskich i podgórskich, odgrywających ważną rolę w gospodarkach turystycznych obu krajów, realizacja sieciowych produktów turystycznych o transgranicznym charakterze ma tu szczególne uzasadnienie i bezpośrednio wpływa na wzbogacanie i uatrakcyjnianie oferty turystycznej na pograniczu. Projekty turystyczne "transgraniczne" w ciągu ostatnich lat stawały się coraz popularniejszą formą współpracy, którą realizowały przede wszystkim JST oraz organizacje pozarządowe korzystające ze wsparcia funduszy unijnych. Zakończenie okresu unijnej perspektywy finansowej 2007-2013 jest sprzyjającym momen- 
tem na podsumowanie dotychczasowych efektów tej współpracy poprzez analizę powstałych na badanym obszarze transgranicznych sieciowych produktów turystycznych (TSPT). Celem opracowania jest rozpoznanie kierunków i dynamiki ich rozwoju poprzez identyfikację projektów współfinansowanych ze środków unijnych w latach 2005-2014 na obszarze euroregionów Glacensis i Pradziad, kreujących lub rozwijających TSPT. Zastosowano metody badawcze: krytycznej analizy literatury przedmiotu, obserwacji bezpośredniej, a także analizy danych dotyczących projektów dofinansowanych ze środków unijnych programów polityki spójności.

\section{Transgraniczne sieciowe produkty turystyczne na obszarze euroregionów Glacensis i Pradziad}

Polska Organizacja Turystyczna definiuje sieciowy produkt turystyczny jako spakietyzowaną ofertę, która opiera się na rozproszonej strukturze miejsc, podmiotów, atrakcji, obiektów i punktów obsługi, funkcjonującą jako spójna koncepcja i posiadającą wspólną markę (http://www.gov.pl). W definicji Polskiej Agencji Rozwoju Turystyki podkreślono również, że innymi charakterystycznymi cechami tego typu produktów są (BUTOWSKI 2010): zawiązywanie porozumienia, które ma na celu uzyskanie korzyści skali, opracowanie wysokiej jakości rozwiązań, pokonywanie sztucznych granic administracyjnych, współpraca podmiotów publicznych i prywatnych oraz możliwość starania się o fundusze zewnętrzne. W toku badań przyjęto, że TSPT, o których mowa w pracy (KRAWCZYSZYN-POCHŁOPIEŃ 2016):

1) są złożone $z$ atrakcji, obiektów, miejsc i innych elementów;

2) są oferowane na rynku turystycznym jako całość (spójna);

3) posiadają spójną koncepcję i wspólną markę promocyjną (wyróżnik);

4) swoim zasięgiem wykraczają poza granicę państwa.

Objęte badaniem obszary dwustronnych euroregionów Glacensis i Pradziad są jednostkami podobnymi pod wieloma względami. Charakteryzują się centralnym położeniem na polsko-czeskim pograniczu, najbardziej licznymi i zaawansowanymi formami współpracy transgranicznej oraz silnym ukierunkowaniem na rozwój turystyki. Wynika ono z ich położenia na obszarze górskim Sudetów charakteryzującym się wysokiej rangi walorami turystycznymi (KRAWCZYSZYN-POCHŁOPIEŃ 2016). Wśród celów współpracy zawartych w statutach euroregionów Glacensis i Pradziad wymieniane są 
m.in.: rozwój turystyki na obszarze przygranicznym, wspieranie rozwoju gospodarczego, usprawnianie ruchu granicznego, ochrona środowiska oraz opieka nad wspólnym dziedzictwem kulturowym (BORYS 1999). Każdy $\mathrm{z}$ nich bezpośrednio lub pośrednio łączy się z rozwojem turystyki, oddziałując na atrakcyjność turystyczną terenu. Oba badane euroregiony posiadają prawie dwudziestoletni staż funkcjonowania, dzięki czemu liczba zrealizowanych na ich obszarze projektów transgranicznych, w tym tworzących TSPT, jest znacząca (KRAWCZYSZYN 2012). Zidentyfikowane podczas badań projekty powstawały głównie w ciągu ostatnich 10 lat. Różniły się zasięgiem, liczbą partnerów, tematyką i założeniami. Analiza danych na temat projektów dofinansowanych z programów unijnych wspierających współpracę transgraniczną na pograniczu polsko-czeskim oparta była przede wszystkim na następujących źródłach (KRAW-CZYSZYN-POCHŁOPIEŃ 2016):

1) strona internetowa programu Europejskiej Współpracy Terytorialnej Republika Czeska - Rzeczpospolita Polska 2007-2013 (http://www. cz-pl.eu/pl; materiały z posiedzeń Komitetów Monitorujących);

2) strony internetowe euroregionów Glacensis (http:/ / www.euroregion glancensis.ng.pl) i Pradziad (http:/ / www.europradziad.pl; dane o projektach realizowanych w ramach Funduszu Mikroprojektów);

3) Mapa dotacji UE (http:/ /www.mapadotacji.pl) wykorzystana pomocniczo (brak niektórych danych, np. okresu realizacji projektów);

4) strona internetowa czeskiego Regionalnego Serwisu Informacyjnego, prowadzonego przez Centrum Rozwoju Regionalnego Republiki Czeskiej (http:// www.risy.cz).

Stworzona dzięki kompilacji baza danych pozwoliła zidentyfikować 50 projektów, które wykreowały 29 sieciowych produktów turystycznych o charakterze transgranicznym. Ze względu na rodzaj zaklasyfikowano je subiektywnie do pięciu grup (KRAWCZYSZYN-POCHŁOPIEŃ 2016), jako produkty:

1) oparte na postaciach historycznych (związanych $z$ ich dokonaniami);

2) oparte na walorach dóbr kultury (np. szlaki miejskie);

3) oparte na walorach naturalnych (np. ścieżki rowerowe);

4) oparte na organizacji cyklicznych wydarzeń (np. festiwale transgraniczne);

5) obszarowe (kreujące odrębny subregion turystyczny).

W pierwszej grupie zidentyfikowano dwa produkty turystyczne wykreowane przy udziale pięciu projektów współfinansowanych ze środków pomocowych UE. Produkty te są oparte o postacie i dziedzictwo królewny 
Marianny Orańskiej oraz pioniera hydroterapii Vincentego Priessnitza. Projekty te zrealizowano w latach 2007-2011 (tab. 1).

Tab. 1. Transgraniczne sieciowe produkty turystyczne na obszarze euroregionów Glacensis i Pradziad oparte na postaciach historycznych

\begin{tabular}{|c|c|c|c|c|}
\hline Lp. & $\begin{array}{l}\text { Produkt/ } \\
\text { idea }\end{array}$ & Projekty składowe & $\begin{array}{l}\text { Czas } \\
\text { realizacji }\end{array}$ & $\begin{array}{l}\text { Zasięg } \\
\text { (powiat) }\end{array}$ \\
\hline \multirow[t]{3}{*}{1.} & \multirow[t]{3}{*}{$\begin{array}{l}\text { Marianna } \\
\text { Orańska }\end{array}$} & $\begin{array}{l}\text { Projekt Ścieżka historyczno-przyrodnicza śladami królewny } \\
\text { Marianny Orańskiej }\end{array}$ & $2007-2010$ & \multirow{3}{*}{$\begin{array}{l}\text { Jesenik, } \\
\text { ząbko- } \\
\text { wicki, } \\
\text { kłodzki }\end{array}$} \\
\hline & & $\begin{array}{l}\text { Projekt Transgraniczny szlak królewny Marianny Orań- } \\
\text { skiej - etap I i II, szlak samochodowy (opracowanie } \\
\text { przygotowawcze, oznakowanie, promocja) }\end{array}$ & 2008-2011 & \\
\hline & & $\begin{array}{l}\text { Projekt Ślady Marianny Orańskiej w Gminie Stronie } \\
\text { Śląskie, imprezy promocyjne }\end{array}$ & 2010 & \\
\hline \multirow[t]{2}{*}{2.} & \multirow[t]{2}{*}{$\begin{array}{l}\text { Vincent } \\
\text { Priessnitz }\end{array}$} & $\begin{array}{l}\text { Projekt Dziedzictwo Vincentego Priessnitza na pogra- } \\
\text { niczu polsko-czeskim, promocja parków zdrojowych, } \\
\text { tradycji uzdrowiskowych }\end{array}$ & $2008-2010$ & \multirow[t]{2}{*}{$\begin{array}{l}\text { Jesenik, } \\
\text { nyski }\end{array}$} \\
\hline & & $\begin{array}{l}\text { Projekt Górskie szlaki Vincentego Priessnitza na pogra- } \\
\text { niczu nysko-jesenickim, stworzenie transgranicznej } \\
\text { ścieżki edukacyjnej V. Priessnitza o historii hydro- } \\
\text { terapii i SPA }\end{array}$ & 2010 & \\
\hline
\end{tabular}

Źródło: opracowanie własne na podstawie: http://www.cz-pl.eu/pl, map projektów EWT 2007-2013 w województwie dolnośląskim i śląskim, stron internetowych euroregionów Glacensis i Pradziad, Mapy dotacji UE, strony internetowe Regionalnego Serwisu Informacyjnego (cz. Regionální Informační Serwis, RIS), cyt. za: N. KRAWCZYSZYN-POCHEOPIEŃ (2016).

Wśród produktów opartych na walorach dóbr kultury w badanych euroregionach Glacensis i Pradziad zidentyfikowano trzy sieciowe produkty turystyczne (tab. 2).

Polegają one na stworzeniu tematycznych szlaków turystycznych pieszych, rowerowych i samochodowych. Produkt turystyczny-szlak ma charakter obszarowy i najczęściej, tworząc sieć ustrukturyzowaną poziomo, łączy elementy substytucyjne. Elementy te, zintegrowane w jedną spójną ofertę (np. atrakcje, usługi i inne) stają się komplementarne i zyskują na atrakcyjności (urozmaicenie, wzbogacenie, wydłużenie czasu korzystania z produktu, zwiększony zasięg marketingowy). Przykładowo, w przypadku produktu Szlak Czarownic na Polsko-Czeskim Pograniczu, transgraniczny sieciowy produkt oparto na treści XVII-wiecznych podań dotyczących prześladowań kobiet posądzonych o czary. Do tego wątku nawiązuje wiele miejsc pogranicza nysko-jesenickiego, leżących na wymienionym szlaku, np. 
Grób Czarownicy w Górach Opawskich, Góra Czarownic na północny zachód od Nysy czy Czarci Kamień nad Jesenikiem (ZWOLIŃSKI, red. 2010). Strona internetowa produktu zawiera przydatne informacje dla turystów i umożliwia pobranie elektronicznego przewodnika rowerowego. Produkt został także wzbogacony o program lojalnościowy (regionalna odznaka kolarska; KRAWCZYSZYN-POCHŁOPIEŃ 2016) Pozostałe dwa zidentyfikowane produkty oparte na walorach dóbr kultury to: trasy turystyczne $\mathrm{w}$ miastach (Citywalk) oraz internetowa baza atrakcji powiązanych tematycznie (Ścieżka czasu).

Tab. 2. Transgraniczne sieciowe produkty turystyczne na obszarze euroregionów Glacensis i Pradziad oparte na walorach dóbr kultury

\begin{tabular}{|c|c|c|c|c|}
\hline Lp. & Produkt / idea & Projekty składowe & $\begin{array}{l}\text { Czas } \\
\text { realizacji }\end{array}$ & Zasięg (powiaty) \\
\hline 1. & $\begin{array}{l}\text { Citywalk - } \\
\text { miejskie trasy } \\
\text { turystyczne }\end{array}$ & $\begin{array}{l}\text { Projekt Miejskie trasy turystyczne zintegro- } \\
\text { wanym produktem turystycznym miast czesko- } \\
\text {-polskiego pogranicza, trasy miejskie po naj- } \\
\text { ważniejszych atrakcjach, system oznakowa- } \\
\text { nia, wspólna promocja }\end{array}$ & 2008-2011 & $\begin{array}{l}\text { kłodzki, Prerov, } \\
\text { świdnicki, } \\
\text { kędzierzyńsko- } \\
\text {-kozielski, ząbko- } \\
\text { wicki, Nachod }\end{array}$ \\
\hline \multirow[t]{3}{*}{2.} & \multirow{3}{*}{$\begin{array}{l}\text { Szlak } \\
\text { czarownic na } \\
\text { polsko-czeskim } \\
\text { pograniczu }\end{array}$} & $\begin{array}{l}\text { Projekt Szlakiem czarownic po czesko-polskim } \\
\text { pograniczu, stworzenie tematycznego szlaku } \\
\text { rowerowego, wydanie przewodnika }\end{array}$ & 2008-2010 & \multirow[t]{3}{*}{$\begin{array}{l}\text { nyski, Jesenik, } \\
\text { Sumperk }\end{array}$} \\
\hline & & $\begin{array}{l}\text { Projekt Szlakiem czarownic po polsko-czeskim } \\
\text { pograniczu, strona internetowa, film promo- } \\
\text { cyjny }\end{array}$ & 2012-2015 & \\
\hline & & $\begin{array}{l}\text { Projekt Zdobądź szlak czarownic, system przy- } \\
\text { znawania regionalnej odznaki kolarskiej }\end{array}$ & 2010 & \\
\hline 3. & Ścieżka czasu & $\begin{array}{l}\text { Projekt Podróżowanie w czasie, baza polsko- } \\
\text { czeskich atrakcji, których motywem łączą- } \\
\text { cym jest czas, folder letni i zimowy, pro- } \\
\text { mocja, imprezy }\end{array}$ & 2010-2012 & $\begin{array}{l}\text { Olomouc, brzeski, } \\
\text { opolski, nyski, } \\
\text { kluczborski, }\end{array}$ \\
\hline
\end{tabular}

Źródło: opracowanie własne na podstawie: http://www.cz-pl.eu/pl, map projektów EWT 2007-2013 w województwie dolnośląskim i śląskim, stron internetowych euroregionów Glacensis i Pradziad, Mapy dotacji UE, strony internetowe Regionalnego Serwisu Informacyjnego (cz. Regionální Informační Serwis, RIS), cyt. za: N. KRAWCZYSZYN-POCHŁOPIEŃ (2016).

W przypadku produktów obszaru polsko-czeskiego pogranicza opartych na walorach naturalnych można stwierdzić, że ich charakter jest bardziej zróżnicowany (tab. 3). 
Tab. 3. Transgraniczne sieciowe produkty turystyczne na obszarze euroregionów Glacensis i Pradziad oparte na walorach naturalnych

\begin{tabular}{|c|c|c|c|c|}
\hline Lp. & Produkt / idea & Projekty składowe & $\begin{array}{l}\text { Czas } \\
\text { realizacji }\end{array}$ & $\begin{array}{l}\text { Zasięg } \\
\text { (powiat) }\end{array}$ \\
\hline \begin{tabular}{|l|}
{$[1]$} \\
\end{tabular} & [2] & [3] & [4] & [5] \\
\hline 1. & $\begin{array}{l}\text { Szlak Wędrówki } \\
\text { po Wieżach } \\
\text { Widokowych }\end{array}$ & $\begin{array}{l}\text { Projekt Miejsca petne widoków w Euroregionie } \\
\text { Glacensis, stworzenie szlaku wież widokowych }\end{array}$ & $2013-2015$ & $\begin{array}{l}\text { Trutnov, Usti } \\
\text { nad Orlici, } \\
\text { kłodzki }\end{array}$ \\
\hline \multirow[t]{2}{*}{2.} & \multirow[t]{2}{*}{$\begin{array}{l}\text { Szlak Widokowy } \\
\text { Szczytami } \\
\text { Pogranicza }\end{array}$} & $\begin{array}{l}\text { Projekt (bliźniaczy do poniższego) Szlak } \\
\text { widokowy Szczytami Pogranicza, wytyczenie } \\
\text { i oznakowanie transgranicznego szlaku wido- } \\
\text { kowego, budowa miejsc wypoczynku i wieży } \\
\text { widokowej }\end{array}$ & 2009 & \multirow[t]{2}{*}{$\begin{array}{l}\text { Jesenik, } \\
\text { kłodzki }\end{array}$} \\
\hline & & $\begin{array}{l}\text { Projekt (bliźniaczy do powyższego) Trasa wido- } \\
\text { kowa wzdtuż grzbietów gór granicznych, stworze- } \\
\text { nie po polskiej i czeskiej stronie szlaku wido- } \\
\text { kowego szczytami pogranicza }\end{array}$ & 2009 & \\
\hline 3. & Widoki bez granic & $\begin{array}{l}\text { Projekt Widoki bez granic, } \\
\text { stworzenie szlaku punktów widokowych }\end{array}$ & 2010 & $\begin{array}{l}\text { kłodzki, } \\
\text { Nachod }\end{array}$ \\
\hline 4. & $\begin{array}{l}\text { Park Obszaru Gór } \\
\text { Stołowych } \\
\text { i Ścian } \\
\text { Broumovskich }\end{array}$ & $\begin{array}{l}\text { Projekt Wspieranie rozwoju ruchu turystycznego } \\
\text { na obszarze Gór Stołowych i Broumowskich Sten - } \\
1 \text { i } 2 \text { etap, dokumentacja dla produktu turys- } \\
\text { tycznego, wspólne imprezy kulturalne, sporto- } \\
\text { we i turystyczne, rewitalizacja infrastruktury }\end{array}$ & $2010-2013$ & $\begin{array}{l}\text { kłodzki, } \\
\text { Nachod }\end{array}$ \\
\hline 5. & Zielone Gościńce & $\begin{array}{l}\text { Projekt Zielone Gościńce - sieć turystyki wiejskiej } \\
\text { oparta na dziedzictwie kulturowym regionu } \\
\text { Opolszczyzny i Jeseników, wspólna oferta, } \\
\text { wspólna promocja }\end{array}$ & 2005-2006 & $\begin{array}{l}\text { opolski, } \\
\text { Jesenik }\end{array}$ \\
\hline 6. & $\begin{array}{l}\text { Geostrada } \\
\text { Sudecka }\end{array}$ & $\begin{array}{l}\text { Projekt Geostrada Sudecka, przewodnik geologicz- } \\
\text { no-turystyczny, samochodowy szlak geotury- } \\
\text { styczny, przewodnik, strona internetowa }\end{array}$ & $2010-2013$ & $\begin{array}{l}\text { obszar przy- } \\
\text { graniczny } \\
\text { Glacensis } \\
\text { i Pradziad }\end{array}$ \\
\hline 7. & $\begin{array}{l}\text { Geopark Niecki } \\
\text { Śródsudeckiej }\end{array}$ & $\begin{array}{l}\text { Projekt Geoturystyka: robimy pierwszy krok, dzia- } \\
\text { łania promujące geoturystykę po obu stronach } \\
\text { granicy, materiały informacyjne, opracowanie } \\
\text { dokumentacji technicznej geoparku }\end{array}$ & 2012-2014 & $\begin{array}{l}\text { kłodzki, } \\
\text { Nachod }\end{array}$ \\
\hline 8. & $\begin{array}{l}\text { Szlak Geoturysty- } \\
\text { czny Pradziad }\end{array}$ & $\begin{array}{l}\text { Projekt Szlak Geoturystyczny Pradziad: Inwenta- } \\
\text { ryzacja i dokumentacja stanowisk, badania, stwo- } \\
\text { rzenie dokumentacji szlaku geologicznego - } \\
\text { produktu opartego o stanowiska geologiczne } \\
\text { i paleontologiczne w Polsce i Czechach }\end{array}$ & 2012 & $\begin{array}{l}\text { opolski, } \\
\text { strzelecki, } \\
\text { oleski, Jese- } \\
\text { nik, nyski, } \\
\text { Prerov }\end{array}$ \\
\hline 9. & $\begin{array}{l}\text { Zdrowie } \\
\text { i relaks na } \\
\text { pograniczu }\end{array}$ & $\begin{array}{l}\text { Projekt Zdrowie i relaks na pograniczu, wspólna } \\
\text { promocja w oparciu o wspólne walory uzdro- } \\
\text { wiskowe, organizacja imprez, modernizacja } \\
\text { obiektów }\end{array}$ & 2012 & $\begin{array}{l}\text { Nachod, } \\
\text { kłodzki }\end{array}$ \\
\hline
\end{tabular}




\begin{tabular}{|c|c|c|c|c|}
\hline$[1]$ & [2] & [3] & [4] & [5] \\
\hline 10. & $\begin{array}{l}\text { Spacery po } \\
\text { miastach uzdrowi- } \\
\text { skowych }\end{array}$ & $\begin{array}{l}\text { Projekt Spacery po miastach uzdrowiskowych- } \\
\text { Jesenik i Gtuchołazy, uzdrowiskowe szlaki } \\
\text { turystyczne, przewodnik }\end{array}$ & $2009-2010$ & $\begin{array}{l}\text { nyski, } \\
\text { Jesenik }\end{array}$ \\
\hline 11. & $\begin{array}{l}\text { Bez-Granicznie } \\
\text { Aktywni }\end{array}$ & $\begin{array}{l}\text { Projekt Bez-Granicznie Aktywni w Euroregionie } \\
\text { Glacensis, oferta turystyczna dla osób starszych } \\
\text { i niepełnosprawnych, atlas turystyczny }\end{array}$ & 2012 & $\begin{array}{l}\text { Usti nad } \\
\text { Orlici, } \\
\text { kłodzki }\end{array}$ \\
\hline 12. & Strefa MTB & $\begin{array}{l}\text { Projekt Kreowanie i promocja transgranicznego } \\
\text { produktu turystycznego - Strefa MTB, strona } \\
\text { internetowa, } 150 \mathrm{~km} \text { tras rowerowych, połą- } \\
\text { czenie tras po polskiej i czeskiej stronie granicy }\end{array}$ & 2006-2007 & $\begin{array}{l}\text { wałbrzyski, } \\
\text { Nachod, } \\
\text { świdnicki }\end{array}$ \\
\hline 13. & $\begin{array}{l}\text { Głuchołasko- } \\
\text { zlatohorskie } \\
\text { zagłębie złota }\end{array}$ & $\begin{array}{l}\text { Projekt Górnicze Tradycje - turystyczna promocja } \\
\text { gtuchołasko-zlatohorskiego zagłębia złota, odno- } \\
\text { wienie szlaków turystycznych w rejonie Głu- } \\
\text { chołaz, tablice informacyjne }\end{array}$ & 2005 & nyski, Jesenik \\
\hline 14. & $\begin{array}{l}\text { Termy, Góry } \\
\text { i Cuda Natury }\end{array}$ & $\begin{array}{l}\text { Projekt Wzrost konkurencyjności tras turystycz- } \\
\text { nych pogranicza gmin Lądek-Zdrój oraz Javornik, } \\
\text { odnowienie transgranicznego szlaku turystycz- } \\
\text { nego, promocja atrakcji we wspólnym pakiecie }\end{array}$ & 2014 & $\begin{array}{l}\text { kłodzki, } \\
\text { Jesenik }\end{array}$ \\
\hline 15. & $\begin{array}{l}\text { Trasy rowerowe } \\
\text { na Pograniczu } \\
\text { Kłodzkim }\end{array}$ & $\begin{array}{l}\text { Projekt Trasy rowerowe na Pograniczu Kłodzkim } \\
\text { I-III etap, sieć szlaków rowerowych na } \\
\text { obszarze pogranicza kłodzkiego }\end{array}$ & 2009-2011 & $\begin{array}{l}\text { Nachodź, } \\
\text { kłodzki }\end{array}$ \\
\hline
\end{tabular}

Źródło: opracowanie własne na podstawie: http://www.cz-pl.eu/pl, map projektów EWT 2007-2013 w województwie dolnośląskim i śląskim, stron internetowych euroregionów Glacensis i Pradziad, Mapy dotacji UE, strony internetowe Regionalnego Serwisu Informacyjnego (cz. Regionální Informační Serwis, RIS), cyt. za: N. KRAWCZYSZYN-POCHŁOPIEŃ (2016).

Najczęściej realizowanymi $\mathrm{w}$ ramach polsko-czeskich projektów turystycznych produktami sieciowymi tego typu są szlaki (piesze i rowerowe), a także parki tematyczne i sieci współpracy tworzące wspólne oferty turystyczne. W przypadku trzech spośród 15 zidentyfikowanych produktów sieciowych tego typu motywem przewodnim są atrakcje geologiczne. Jeden z nich, Geostrada Sudecka, obejmuje cały obszar pogranicza polsko-czeskiego, wykraczając poza granice badanych euroregionów.

Na obszarze euroregionów Glacensis i Pradziad zidentyfikowano także nieliczne produkty turystyczne będące transgranicznymi, cyklicznymi wydarzeniami (tab. 4).

W badanych euroregionach odbywa się wiele imprez i wydarzeń, nazywanych transgranicznymi, jednak $\mathrm{w}$ rzeczywistości rzadko są to trwałe produkty turystyczne dostępne po obu stronach granicy. Z tego względu za TSPT $\mathrm{w}$ tej kategorii uznano tylko dwie marki turystyczne funkcjonujące na obszarze euroregionów Glacensis i Pradziad. Przykładem zaawansowanego pro- 
duktu tego typu jest Fortfan - pogranicze wo ogniu, w ramach którego w latach 2008-2011 na terenie trzech czeskich regionów i dwóch polskich województw odbyło się ponad 30 rekonstrukcji historycznych bitew. W ramach projektu ustalono wspólny terminarz imprez i wydano tzw. paszporty Fortfana, działające na zasadzie programu lojalnościowego. Zrealizowano także m.in. „,żywe” lekcje historii w szkołach (KRAWCZYSZYN 2011).

Z przeprowadzonej na potrzeby opracowania analizy wynika, że najchętniej tworzone sieciowe produkty turystyczne o charakterze transgranicznym to produkty typu obszarowego (tab. 5).

Tab. 4. Transgraniczne sieciowe produkty turystyczne na obszarze euroregionów Glacensis i Pradziad oparte na cyklicznych transgranicznych wydarzeniach

\begin{tabular}{|c|l|l|l|l|}
\hline Lp. & $\begin{array}{l}\text { Produkt / } \\
\text { idea }\end{array}$ & \multicolumn{1}{|c|}{ Projekty składowe } & $\begin{array}{c}\text { Czas } \\
\text { realizacji }\end{array}$ & \multicolumn{1}{|c|}{ Zasięg } \\
\hline 1. & $\begin{array}{l}\text { Fortfan - } \\
\text { pogranicze } \\
\text { w ogniu }\end{array}$ & $\begin{array}{l}\text { Projekt Rekonstrukcje historyczne wspólnym } \\
\text { produktem turystycznym polsko-czeskiego } \\
\text { pogranicza, rekonstrukcje historycznych } \\
\text { bitew po polskiej i czeskiej stronie granicy, } \\
\text { współpraca regimentów, wspólny } \\
\text { kalendarz imprez }\end{array}$ & $\begin{array}{l}\text { 2008-2011 } \\
\text { kłodzki, Hradec Kralove, } \\
\text { świdnicki, kędzierzyń- } \\
\text { sko-kozielski, nyski, } \\
\text { Jesenik, Usti nad Orlici, } \\
\text { ząbkowicki, Nachod }\end{array}$ \\
\hline 2. & $\begin{array}{l}\text { Cyklo } \\
\text { Glacensis }\end{array}$ & $\begin{array}{l}\text { Projekt Cyklo Glacensis, cykliczny rajd } \\
\text { w formule zlotu gwiaździstego z kilkuna- } \\
\text { stu miast polskich i czeskich, organizowa- } \\
\text { ny corocznie w latach 2007-2015 }\end{array}$ & 2007-2015 & $\begin{array}{l}\text { kłodzki, Usti nad Orlici, } \\
\text { Nachod }\end{array}$ \\
\hline
\end{tabular}

Źródło: opracowanie własne na podstawie: http://www.cz-pl.eu/pl, map projektów EWT 2007-2013 w województwie dolnośląskim i śląskim, stron internetowych euroregionów Glacensis i Pradziad, Mapy dotacji UE, strony internetowe Regionalnego Serwisu Informacyjnego (cz. Regionální Informační Serwis, RIS), cyt. za: N. KRAWCZYSZYN-POCHŁOPIEŃ (2016).

Tab. 5. Transgraniczne sieciowe produkty turystyczne na obszarze euroregionów Glacensis i Pradziad o charakterze obszarowym

\begin{tabular}{|c|c|c|c|c|}
\hline Lp. & Produkt/idea & Projekty składowe & $\begin{array}{c}\text { Czas } \\
\text { realizacji }\end{array}$ & Zasięg \\
\hline [1] & [2] & [3] & [4] & [5] \\
\hline 1. & $\begin{array}{l}\text { Kraina Gór } \\
\text { Stołowych }\end{array}$ & $\begin{array}{l}\text { Projekt Kreowanie i promocja transgranicznych produktów } \\
\text { turystycznych z wykorzystaniem zasobów dziedzictwa ku- } \\
\text { lturowego i naturalnego szansa dla rozwoju gospodarki re- } \\
\text { gionalnej Gór Stołowych - Etap I - Kraina Gór Stołowych, } \\
\text { podpisanie porozumień, oznakowanie tras turystycz- } \\
\text { nych, akcje promocyjne, publikacje, nowe produkty } \\
\text { turystyczne - imprezy, strona internetowa, trasa } \\
\text { turystyczna }\end{array}$ & $2006-2007$ & $\begin{array}{l}\text { kłodzki, } \\
\text { Nachod }\end{array}$ \\
\hline
\end{tabular}




\begin{tabular}{|c|c|c|c|c|}
\hline [1] & [2] & [3] & [4] & [5] \\
\hline \multirow[t]{3}{*}{2.} & \multirow[t]{3}{*}{$\begin{array}{l}\text { Kłodzko- } \\
\text {-Orlicko }\end{array}$} & $\begin{array}{l}\text { Projekt Kłodzko - Orlicko: wszystko i jeszcze więcej, pakie- } \\
\text { ty turystyczne: uzdrowiska i kultura, mapa pogranicza, } \\
\text { gra komputerowa o pograniczu, strona internetowa }\end{array}$ & 2005-2008 & \multirow{3}{*}{$\begin{array}{l}\text { kłodzki, } \\
\text { Rychnov } \\
\text { nad } \\
\text { Kneznou }\end{array}$} \\
\hline & & $\begin{array}{l}\text { Projekt Wspólna promocja Ziemi Kłodzkiej, Gór Orlickich } \\
\text { i Podorlicka, promocja, materiały, wydawnictwa }\end{array}$ & 2010 & \\
\hline & & $\begin{array}{l}\text { Projekt Kladsko-Orlicko - wspólna motywacyjno - promo- } \\
\text { cyjna kampania, wypracowanie systemu oferty tury- } \\
\text { stycznej i programu rabatowego dla turystów, opra- } \\
\text { cowanie planu działań współpracy transgranicznej }\end{array}$ & 2013-2014 & \\
\hline \multirow[t]{8}{*}{3.} & \multirow{8}{*}{$\begin{array}{l}\text { Pogranicze } \\
\text { nysko- } \\
\text {-jesenickie }\end{array}$} & $\begin{array}{l}\text { Projekt Promocja atrakcji turystycznych pogranicza nysko- } \\
\text {-jesenickiego, szlak samochodowy, atlas turystyczny }\end{array}$ & 2006-2007 & \multirow[t]{8}{*}{$\begin{array}{l}\text { nyski, } \\
\text { Jesenik }\end{array}$} \\
\hline & & $\begin{array}{l}\text { Projekt Tradycje turystyczne pogranicza nysko-jesenic- } \\
\text { kiego, wspólne publikacje, album promocyjny }\end{array}$ & 2006 & \\
\hline & & $\begin{array}{l}\text { Projekt Dziedzictwo przyrodnicze pogranicza nysko-jese- } \\
\text { nickiego, album promocyjny o przyrodzie i regionie, } \\
\text { konferencja }\end{array}$ & 2006 & \\
\hline & & $\begin{array}{l}\text { Projekt Wspólne dziedzictwo pogranicza nysko-jesenickiego } \\
\text { Euroregionu Pradziad, konferencja, wspólne publikacje }\end{array}$ & 2008-2009 & \\
\hline & & $\begin{array}{l}\text { Projekt Poznawanie pociagiem jesenicko-nyskiego pograni- } \\
\text { cza, imprezy rekreacyjne, rozmieszczenie tablic infor- } \\
\text { macyjnych o atrakcjach turystycznych na dworcach } \\
\text { kolejowych i autobusowych, organizacja turystycz- } \\
\text { nych przejazdów koleją, promocja }\end{array}$ & 2009 & \\
\hline & & $\begin{array}{l}\text { Projekt Szlaki turystyczne pogranicza nysko-jesenickiego, } \\
\text { oznaczenie atrakcji turystycznych po stronie polskiej, } \\
\text { wydanie albumu o atrakcjach pogranicza nysko-jese- } \\
\text { nickiego }\end{array}$ & 2006-2007 & \\
\hline & & $\begin{array}{l}\text { Projekt Jesenicko-nyskie górskie pojezierze, konferencja nt. } \\
\text { rozwoju turystyki, wspólny udział w targach, wydanie } \\
\text { materiałów promocyjnych, promocja w mediach } \\
\text { regionu nysko-jesenickiego jako całości }\end{array}$ & 2012-2013 & \\
\hline & & $\begin{array}{l}\text { Projekt Witajcie u nas - w regionie nysko-jesenickim, kam- } \\
\text { pania promocyjna, materiały informacyjne }\end{array}$ & 2010 & \\
\hline 4. & $\begin{array}{l}\text { Księstwo } \\
\text { Nyskie }\end{array}$ & $\begin{array}{l}\text { Projekt Dziedzictwo księstwa nyskiego i wspólna historia } \\
\text { w Jeseniku } i \text { Głuchołazach, wspólne ścieżki rowerowe }\end{array}$ & 2014-2015 & $\begin{array}{l}\text { Jesenik, } \\
\text { nyski }\end{array}$ \\
\hline \multirow[t]{3}{*}{5.} & $\begin{array}{l}\text { Hrabstwo } \\
\text { Kłodzkie }\end{array}$ & $\begin{array}{l}\text { Projekt Turystyczne Paszporty Hrabstwa Kłodzkiego - } \\
\text { otwarta droga na polsko - czeskie pogranicze, rozbudo- } \\
\text { wany projekt opierający się na katalogu atrakcji i oferty } \\
\text { rabatowej na pograniczu polsko-czeskim w polskiej } \\
\text { i czeskiej wersji językowej }\end{array}$ & 2009 & \multirow[t]{3}{*}{$\begin{array}{l}\text { kłodzki, } \\
\text { Usti nad } \\
\text { Orlici, } \\
\text { Rychnov } \\
\text { nad } \\
\text { Kneznou }\end{array}$} \\
\hline & & $\begin{array}{l}\text { Projekt Hrabstwo dla każdego, dla matego i dużego, tury- } \\
\text { styczna oferta pogranicza polsko-czeskiego, oferty tury- } \\
\text { styczne dla trzech grup wiekowych }\end{array}$ & 2011 & \\
\hline & & $\begin{array}{l}\text { Projekt Wakacje w Hrabstwie Kłodzkim - oferta turystyki } \\
\text { rodzinnej na pograniczu polsko-czeskim, folder promo- } \\
\text { cyjny o miejscach przyjaznych rodzinom po stronie } \\
\text { polskiej i czeskiej }\end{array}$ & 2013-2014 & \\
\hline
\end{tabular}




\begin{tabular}{|c|c|c|c|c|}
\hline [1] & [2] & [3] & [4] & [5] \\
\hline cd. & $\begin{array}{l}\text { Hrabstwo } \\
\text { Kłodzkie }\end{array}$ & $\begin{array}{l}\text { Projekt Hrabstwo Kłodzkie - Kraina Pstraga, promocja } \\
\text { Ziemi Kłodzkiej jako miejsca odpoczynku na łonie } \\
\text { natury i atrakcyjnych łowisk pstrąga, organizacja } \\
\text { Festiwalu Pstrąga, wydanie materiałów promocyj- } \\
\text { nych w dwóch językach, promocja po obu stronach } \\
\text { granicy }\end{array}$ & 2012 & $\begin{array}{l}\text { kłodzki, } \\
\text { Usti nad } \\
\text { Orlici, } \\
\text { Rychnov } \\
\text { nad } \\
\text { Kneznou }\end{array}$ \\
\hline \multirow[t]{4}{*}{6.} & \multirow[t]{4}{*}{$\begin{array}{l}\text { Region } \\
\text { Hranicko } \\
\text { i Dolina } \\
\text { Małej Panwi }\end{array}$} & $\begin{array}{l}\text { Projekt Rozwój tras rowerowych w Regionie Hranicko } \\
\text { i Dolinie Matej Panwi - Gmina Kolonowskie, wspólna } \\
\text { promocja atrakcji, oznakowanie zdewastowanych } \\
\text { tras rowerowych, budowa miejsc postojowych, } \\
\text { wydanie materiałów promocyjno-informacyjnych }\end{array}$ & 2011 & \multirow[t]{4}{*}{$\begin{array}{l}\text { strzelecki, } \\
\text { Prerov }\end{array}$} \\
\hline & & $\begin{array}{l}\text { Projekt Rozwój tras rowerowych w Regionie Hranicko } \\
\text { i Dolinie Małej Panwi - Gmina Jemielnica, stworzenie } \\
\text { oferty spędzania wolnego czasu dla turystów zagra- } \\
\text { nicznych, wspólne imprezy, odnowienie ścieżek } \\
\text { rowerowych, wyposażenie ich w nowoczesną } \\
\text { infrastrukturę }\end{array}$ & $2010-2011$ & \\
\hline & & $\begin{array}{l}\text { Projekt Promocja walorów turystycznych Regionu Hra- } \\
\text { nicko i Doliny Małej Panwi, dokumenty strategiczne, } \\
\text { punkty informacyjne, mapy ścieżek rowerowych, } \\
\text { materiały promocyjne, spotkania, imprezy, targi }\end{array}$ & 2008-2010 & \\
\hline & & $\begin{array}{l}\text { Projekt Na rowerze do przeszłości przez Region Hranicko } \\
\text { i Dolinę Małej Panwi, miejsca postojowe na szlakach } \\
\text { rowerowych z dostępem do materiałów informacyj- } \\
\text { nych, wspólna promocja na targach w Polsce } \\
\text { i Czechach, rajdy rowerowe }\end{array}$ & 2011-2013 & \\
\hline 7. & $\begin{array}{l}\text { Kraina Gór } \\
\text { Rychlebskich }\end{array}$ & $\begin{array}{l}\text { Projekt Rozwój oznakowanych szlaków turystycznych } \\
\text { i atrakcji - kraina Gór Rychlebskich, szlaki turystyczne } \\
\text { „Przez Góry Rychebskie” }\end{array}$ & 2010-2012 & $\begin{array}{l}\text { opolski, } \\
\text { Jesenik }\end{array}$ \\
\hline
\end{tabular}

Źródło: opracowanie własne na podstawie: http://www.cz-pl.eu/pl, map projektów EWT 2007-2013 w województwie dolnośląskim i śląskim, stron internetowych euroregionów Glacensis i Pradziad, Mapy dotacji UE, strony internetowe Regionalnego Serwisu Informacyjnego (cz. Regionální Informační Serwis, RIS), cyt. za: N. KRAWCZYSZYN-POCHŁOPIEŃ (2016).

Ich marki powstawały na potrzeby realizacji projektów współfinansowanych ze środków UE i tworzenia ich koncepcji marketingowych (np. Kraina Gór Rychlebskich, Region Hranicko i Dolina Matej Panzwi, Kraina Gór Stołowych, Hrabstwo Kłodzkie) lub na podstawie funkcjonujących już wcześniej w świadomości społeczności lokalnych tradycji, które zostały wtórnie wykorzystane w projektach unijnych (np. Kłodzko-Orlicko, region nysko-jesenicki). Niemniej jednak także marki stworzone na potrzeby projektów mają $\mathrm{w}$ większości odzwierciedlenie $\mathrm{w}$ tradycjach historycznych obszaru. Spośród zidentyfikowanych produktów turystycznych wyróżnia się funkcjonująca od kilkunastu lat marka Hrabstzoo Kłodzkie. 


\section{Dynamika rozwoju TSPT na obszarze euroregionów Glacensis i Pradziad a kształtowanie się transgranicznego regionu turystycznego}

Przeanalizowane TSPT na obszarze euroregionów Glacensis i Pradziad nie tylko stanowią wyraz współpracy transgranicznej $\mathrm{w}$ turystyce, ale także, dzięki sieciowemu charakterowi, wpływają na kształtowanie się gospodarki turystycznej na poziomie szerszym niż lokalny. Tym samym oferowanie ich turystom jako złożonych produktów turystycznych sprzyja identyfikacji obszaru pogranicza polsko-czeskiego jako spójnego regionu turystycznego. Grupą docelową transgranicznych sieciowych produktów turystycznych są zarówno turyści zagraniczni, jak i krajowi z obu państw, na których terytorium funkcjonuje produkt. $Z$ analizy ruchu turystycznego w Polsce i Czechach (przyjazdy krajowe i zagraniczne) w latach 2007-2013 (EUROSTAT 2014) wynika, że przyjazdy na terytorium Polski realizują w przeważającej liczbie turyści krajowi (18,2 mln w 2013 r.), a przyjazdy turystów zagranicznych mają znacznie mniejszy udział (5,2 mln w 2013 r.). Po stronie czeskiej liczba przyjazdów krajowych i zagranicznych jest podobna, przy czym większy odsetek stanowią przyjazdy z zagranicy $(7,6 \mathrm{mln}$ przyjazdów krajowych i 7,9 mln zagranicznych w 2013 r.). Na wyodrębnionym obszarze euroregionów Glacensis i Pradziad, definiowanym za pomocą regionów klasyfikacji NUTS 2 (regiony przylegające do granicy po obu jej stronach), zdecydowanie dominują przyjazdy krajowe. Ogółem liczba przyjazdów w 2013 roku wyniosła ponad 8,2 mln, w tym 6,6 mln krajowych i 1,6 mln zagranicznych. Tendencja jest wzrostowa, dzięki czemu w 2013 roku odnotowano o ponad milion przyjazdów na badany teren pogranicza polsko-czeskiego więcej niż w roku 2009. To pozwala założyć, że jeżeli warunki społeczno-gospodarcze nie zmienią się, turystyka na badanym obszarze będzie nadal się rozwijać. Jednocześnie zmiany $\mathrm{w}$ trendach $\mathrm{w}$ turystyce europejskiej i światowej dają polsko-czeskiemu pograniczu możliwość dalszego, intensywnego rozwoju gospodarki turystycznej. Europa Środkowa i Wschodnia osiąga najszybszy wzrost przyjazdów zagranicznych na całym kontynencie i UNWTO przewiduje, że zainteresowanie tym kierunkiem będzie nadal rosło, $\mathrm{w}$ tempie $4,4 \%$ rocznie (wzrost dwukrotnie szybszy niż w USA czy Europie Zachodniej; UNWTO, 2014). Rozwojowi produktów turystycznych złożonych, w tym TSPT, sprzyjają także społeczne zmiany $\mathrm{w}$ sposobach spędzania wolnego czasu, np. poszukiwanie kontaktu z przyrodą czy turystyczne uprawianie 
sportu i rekreacji. Powstawanie w ostatnich latach TSPT na obszarze euroregionów Glacensis i Pradziad przy wykorzystaniu środków z funduszy unijnych polityki spójności jest związane przede wszystkim z rozwojem nowych form współpracy i dostępnością środków. Największa liczba zidentyfikowanych projektów, których celem było stworzenie bądź rozwój sieciowych produktów turystycznych, powstała $\mathrm{w}$ połowie okresu programowania finansowego 2007-2013 (KRAWCZYSZYN-POCHŁOPIEŃ 2016; rys. 1).

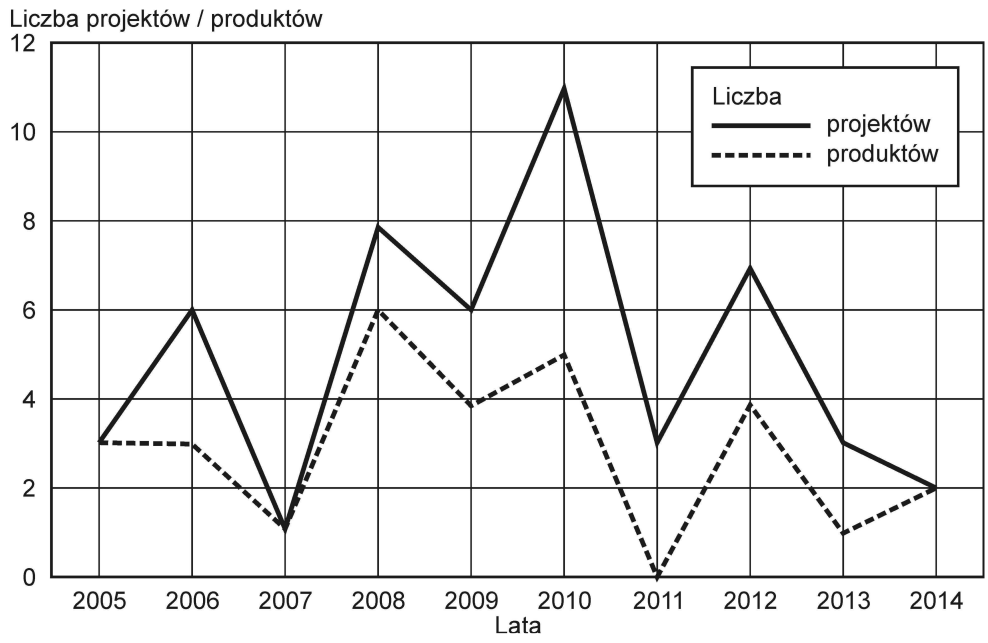

Rys. 1. Transgraniczne sieciowe projekty i produkty turystyczne na obszarze euroregionów Glacensis i Pradziad w latach 2005-2014 (według roku rozpoczęcia ich realizacji/ stworzenia) Źródło: opracowanie własne na podstawie: http:/ / www.cz-pl.eu/pl, map projektów EWT 2007-2013 w województwie dolnośląskim i śląskim, stron internetowych euroregionów Glacensis i Pradziad, Mapy dotacji UE, strony internetowe Regionalnego Serwisu Informacyjnego (cz. Regio-nální Informační Serwis, RIS), cyt. za: N. KRAWCZYSZYN-POCHŁOPIEŃ (2016)

Był to czas, kiedy dostępność środków pomocowych była stosunkowo duża. Pod koniec perspektywy finansowej 2007-2013, przy zmniejszającej się dostępności środków, pozyskanie dofinansowania stało się trudniejsze. W najbardziej owocnym 2010 roku powstało pięć produktów turystycznych, które stworzono dzięki 11 polsko-czeskim projektom dofinansowanym ze środków UE. W 2011 roku rozpoczęto realizację trzech projektów, które rozwijały istniejące TSPT, jednak nie powstał żaden nowy produkt turystyczny tego typu (KRAWCZYSZYN-POCHŁOPIEN 2016). W ramach nowej perspektywy finansowej 2014-2020 w programie Interreg VA Republika Czeska - Polska, 
projekty turystyczne będzie można realizować $w$ ramach drugiej osi priorytetowej. W treści programu istnieje jednak wzmianka, że w zakresie turystyki realizacja programu ma przede wszystkim prowadzić do zwiększenia zatrudnienia $w$ turystyce (http://www.ewt.gov.pl.). Tym samym ograniczono pole dla rozwijania i tworzenia sieciowych produktów turystycznych, zwłaszcza dla głównych beneficjentów - JST, które dotychczas nie musiały realizować projektów bezpośrednio związanych ze zwiększaniem zatrudnienia w branży turystycznej.

\section{Podsumowanie}

Lata 2008-2012 były okresem najbardziej owocnym dla rozwoju współpracy sieciowej i sieciowych produktów turystycznych na obszarze euroregionów Glacensis i Pradziad dzięki dofinansowaniu ze środków pomocowych UE. Był to czas, kiedy na obszarze obu krajów weszły w życie postanowienia Układu z Schengen, zatem realizacja transgranicznych produktów turystycznych pozbawionych bariery granicy państwowej stała się możliwa, a nowy Program Operacyjny Współpracy Transgranicznej Republika Czeska - Rzeczpospolita Polska 2007-2013 pozwolił pozyskiwać na projekty turystyczne (Oś priorytetowa 2. Poprawa warunków rozwoju przedsiębiorczości i turystyki, Działanie 2.2. Wspieranie rozwoju turystyki) nawet do $85 \%$ dofinansowania ze środków EFRR (KRAWCZYSZYN-POCHŁOPIEŃ 2016). Rozwojowi stosunkowo nowej formy współpracy $\mathrm{w}$ turystyce, jaką są transgraniczne sieciowe produkty turystyczne, sprzyjał niemal stały wzrost liczby turystów w Europie. Wśród zidentyfikowanych, powstałych w latach 2005-2014, TSPT największy udział mają produkty oparte na walorach naturalnych, które są głównym elementem atrakcyjności turystycznej pogranicza polsko-czeskiego, oraz produkty obszarowe. Rzadziej produkty oparte na walorach dóbr kultury oraz znanych postaciach historycznych. Współpraca sieciowa w turystyce na obszarze euroregionów Glacensis i Pradziad w ciągu ostatnich ponad 10 lat doprowadziła do pojawienia się na rynku turystycznym oferty transgranicznej, która wciąż jest zjawiskiem stosunkowo rzadko spotykanym na świecie. Jednocześnie warto zwrócić uwagę, że pogranicze polsko-czeskie, wykorzystując trendy na rynku turystycznym i sprzyjające warunki społeczno-gospodarcze, posiada warunki do dalszego rozwoju sieciowego gospodarki turystycznej. Jednak dopiero uruchomienie nowych transgranicz- 
nych programów pomocowych, w których środki na rozwój turystyki są trudniejsze do zdobycia i wreszcie całkowity zanik w przyszłości możliwości dofinansowania tego typu przedsięwzięć z unijnych dotacji (co jest prawdopodobne w kolejnej perspektywie finansowej), pozwoli stwierdzić, czy funkcjonowanie transgranicznych sieciowych produktów turystycznych na obszarze euroregionów Glacensis i Pradziad jest zjawiskiem trwałym, popartym rzeczywistą chęcią nawiązania współpracy.

\section{Bibliografia}

BORYS T., 1999, Cele i dotychczasowy przebieg wspótpracy, [w:] Euroregiony w nowym podziale terytorialnym Polski, H. Dmochowska (red.), GUS Wrocław, Wrocław, s. 62-63.

BUTOWSKI L., 2010, Turystyka jako czynnik rozwoju w świetle wybranych teorii rozwoju regionalnego, „Turyzm/Tourism", 20/1, s. 5-11.

KRAWCZYSZYN N., 2011, Turystyczne marki "Citywalk” $i$ „Fortfan” jako przykład transgranicznej wspótpracy sieciowej, [w:] A. Dybała, J. Potocki (red.), Gospodarka przestrzenna, Prace Naukowe Uniwersytetu Ekonomicznego we Wrocławiu, Wrocław, s. 58-67.

KRAWCZYSZYN N., 2012, Rozwój sieciowy na pograniczu polsko-czeskim - euroregionalny produkt turystyczny, "Barometr Regionalny. Analizy i prognozy”, 2 (28), s. 123-128.

KRAWCZYSZYN-POCHŁOPIEŃ N., 2016, Sieciowe produkty turystyczne jako przedmiot wspótpracy euroregionalnej - studium przypadku pogranicza polsko-czeskiego, praca doktorska napisana pod kier. dr. hab. Zbigniewa Przybyły, prof. UE we Wrocławiu, Jelenia Góra, mps.

ZWOLIŃSKI G. (red.), 2010, Szlakiem czarownic po czesko-polskim pograniczu, Studio Plan, Wrocław.

http:/ / ec.europa.eu/eurostat/data/database; 3.11.2014.

http:/ / www.cz-pl.eu/pl/; 20.03.2015.

http://www.e-unwto.org/doi/pdf/10.18111/9789284416226; 2.06.2015.

http://www.europradziad.pl/index2.php; 10.10.2015.

http:/ / www.euroregion-glacensis.ng.pl/index.php/pl/o-stowarzyszeniu; 10.10.2015.

http:/ / www.ewt.gov.pl/media/15939/ CZ_PL_Program .pdf; 25.07.2016.

http://www.ewt.gov.pl/media/6874/Program_PL_CZ_14-20_23.pdf; 20.08.2015.

http://www.mapadotacji.pl/; 22.03.2015.

http:/ / www.pot.gov.pl/6-4-fundusze-ue/i/2014-03-17-11-58-18/slownik?id=1943:sieciowy-produktturystyczny\&catid=180; 2.01.2013.

http:/ / www.risy.cz/cs/vyhledavace/projekty-eu/; 30.03.-23.04.2015.

http://www.unwto.org/facts/eng/pdf/highlights/UNWTO_Highlights10_en_HR.pdf; 2.09.2015. 